\title{
Seed Size as Key Factor in Germination and Seedling Development of Copaifera langsdorffii (Fabaceae)
}

\author{
Matheus Lopes Souza ${ }^{1,2}$, Marcílio Fagundes ${ }^{*}$ \\ ${ }^{1}$ Laboratório de Biologia da Conservação, Universidade Estadual de Montes Claros, Montes Claros, Brasil \\ ${ }^{2}$ Laboratório de Fisiologia Vegetal, Universidade Federal de Minas Gerais, Belo Horizonte, Brasil \\ Email: ${ }^{*}$ marcillio.fagundes@gmail.com
}

Received 20 May 2014; revised 22 June 2014; accepted 12 July 2014

Copyright (C) 2014 by authors and Scientific Research Publishing Inc.

This work is licensed under the Creative Commons Attribution International License (CC BY). http://creativecommons.org/licenses/by/4.0/

(c) (i) Open Access

\begin{abstract}
Seed size is a plastic trait of the plants that directly affect seed germination and seedling recruitment. This study aimed to investigate the relationship between seed size, seed germinability and seedling performance of Copaifera langsdorffii by testing four hypotheses: 1) larger seeds have higher germination percentage; 2 ) smaller seeds require less time to germinate and for initial development of the seedlings; 3 ) larger seeds produce more vigorous seedlings and 4) seed size negatively affects seedling root/shoot ratio. In 2011, we selected 30 individuals of $C$. langsdorffii from which 300 seeds were randomly collected in the plant canopy. All these seeds were weighted and placed in germination tray using vermiculite as substrate. Seed germinability and initial development of seedlings were monitored daily until cotyledons fell. Small seeds have higher germination percentage and germinate faster when compared to large seeds. Nonetheless, seedlings originated from larger seeds have longer development times, resulting in more vigorous seedlings. In addition, seedlings originating from small seeds allocate proportionally greater amount of resources to roots when compared to larger seeds. The fact that small seeds have higher germination percentage and faster germination favors the colonization of transient habitats. However, larger seeds produce more vigorous seedlings, favoring the seedling establishment in more stable habitats. Thus, we argue that high variability in seed size of $C$. langsdorffii favors its widespread geographic distribution.
\end{abstract}

\section{Keywords}

Community Organization, Plant Distribution, Seed Biometry, Seed Reserves, Seedling Vigor

\footnotetext{
${ }^{*}$ Corresponding author.
} 


\section{Introduction}

Seed germination and seedling establishment are critical stages of the plant life cycles, influencing both distribution and abundance of plant species in communities [1] [2]. In fact, geographic distribution and abundance of some plant species may be associated with variations in seed germinability and seedling recruitment between different habitats due to environmental limitations, such as altitude, topography, soil quality and climate [3]-[5].

Several ecological and evolutionary factors can affect the process of seed germination and further plant establishment [6]. Seed size has been considered an important evolutionary trait that affects the reproductive outcome of many plant species [7]. Seed size directly influences the germination time [8], germination percentage [9] and seedling vigor [10], which can indirectly determine plant distribution and abundance across different habitats [11]. However, seed size produced by plants varies between and within plant species, sometimes by several orders of magnitude [12]-[14].

Smaller seeds generally germinate faster providing greater competitive advantage especially in early successional stages [15]. Nevertheless, larger seeds, although germinating slowly, often have higher percentage of germination than small seeds, being favored in predictable habitats [16]-[18]. Moreover, asynchronous and heterogeneous seed germination observed in several plants species can be associated with intra-specific variation in seed size and allow the species to colonize different habitats and expand their geographic distribution limit [5] [6] [19].

The weight and size of the seeds are directly related to the amount of nutritional reserves that will be allocated for the initial seedling growth [20]. Large seeds tend to produce more vigorous seedlings when compared to small seeds [10]. Greater amount of stored reserves allow a higher probability of seedling establishment at sites with lower resource availability [17]. However, plants respond to their environmental in such way as to optimize their resource use. Thus, according the resource optimization hypothesis, plants allocate relatively less resource to their root system when nutrient availability increases [21] [22]. In this scenario, it is expected that seedlings originated from larger seeds would present smaller root: shoot ratio, as large seeds have more nutritional reserves.

Variation in seed size is an important area of plant ecology because seed size can directly affect the processes of germination and seedling recruitment, influencing the plant performance under different environmental [23] [24]. In Brazil, Copaifera langsdorffii (Fabaceae) presents wide geographic distribution, occurring at different biomes (Brazilian Savannah, Dry Forest, Amazon Rainforest and Atlantic Forest) [25] [26]. Hence, the objective of this study was to evaluate the relationship between seed size, germination and seedling performance of $C$. langsdorffii by testing three hypothesis: 1) smaller seeds require less time to germinate and for initial development of the seedlings; 2) larger seeds have higher germination percentage and produce more vigorous seedlings and 3) seedling root/shoot ratio is negatively affected by seed size.

\section{Material and Methods}

\subsection{Studied Plant}

Copaifera langsdorffii (Fabaceae) is a heliophytic, deciduous tropical tree, growing up to 10 to $15 \mathrm{~m}$ height. The species have a wide distribution, occurring from northern Argentina to southern Bolivia, throughout the Brazilian Cerrado [25]. C. langsdorffii presents supra-annual fruiting, alternating years of high and low or no fruit production. The flowering occurs from November to January and fruits are mature by July to September, coinciding with the time of greatest leaves' deciduousness [26]. Upon opening, each fruit exposes a single ellipsoid seed, which is black and shiny and is partially covered by a yellow-orange aril. The seeds of $C$. langsdorffii have orthodox behavior and slow germination, which extends up to 70 days after sown [27].

\subsection{Seed Collection}

Seeds used in this study were collected from 30 individuals of Copaifera langsdorffii located in an area of Cerrado stricto sensu (16 $\left.46^{\prime} 26^{\prime \prime} \mathrm{S}, 43^{\circ} 48^{\prime} 44^{\prime \prime} \mathrm{W}\right)$ in Montes Claros municipality, north of Minas Gerais State, Brazil. The region have semi-arid climate with well-defined dry and wet seasons. The average annual temperature is about $23^{\circ} \mathrm{C}$ and average rainfall is about $1000 \mathrm{~mm} /$ year. The study area presents dystrophic soils and developed herbaceous-subshrub strata often affected by fire [4] [28].

During August 2011, 30 reproductive individuals of $C$. langsdorffii were selected at study area. Those trees were from five to seven meters high, with a well-formed crown and in a good phytosanitary state (e.g. without presence of lianas or parasitic plants). A total of 100 fruits were haphazardly collected throughout the canopy 
from each selected tree and taken to Laboratory of Conservation Biology of State University of Montes Claros (UNIMONTES). All collected fruits were manually benefited, eliminating malformed seeds and those with visual signals of attacks by predators or pathogens. Thus, a set of 300 seeds (ten seeds per plant) were selected and weighed with an analytical scale. Finally those seeds were categorized in two size classes: smaller seeds (seeds < $0.394 \mathrm{~g}, \mathrm{n}=150$ ) or larger seeds (seeds $>0.397 \mathrm{~g}, \mathrm{n}=150$ ).

\subsection{Germination Experiment}

After seeds were weighed, all 300 seeds were individually sown in germination tray formed by 300 cells (2 cm length, $2 \mathrm{~cm}$ width and $3 \mathrm{~cm}$ height) and vermiculite was used as substrate for seed germination. All seeds were subjected to disinfection in a $1 \%$ sodium hypochlorite solution for two minutes before sown. The germination experiment was conducted in a germination chamber with controlled photoperiod and temperature (12 h/light at $30^{\circ} \mathrm{C}$ e $12 \mathrm{~h} /$ dark at $25^{\circ} \mathrm{C}$ ). The humidity of the substrate was maintained daily by adding three ml of distilled water in each germination cell. The seeds were monitored daily to determine the percentage and time for germination. Seed was considered germinated when they presented primary root protrusion [18].

At the same time, a soaking test was conducted under same germination conditions using others 80 seeds (40 seed for each size class). At this case, dry mass of all seeds was determined and so, all those 80 seeds were immersed in distilled water and weighed after 2, 4, 8, 18, 24, 30 and 48 hours of water absorption. Relative increase in fresh weight $(\mathrm{Wr})$ of seeds was calculated as $\mathrm{Wr}=[(\mathrm{Wf}-\mathrm{Wi}) / \mathrm{Wi}] \times 100$, where Wi is the initial seed weight and Wf the weight after each time of water absorption [29]. Thus, imbibitions curves for smaller and larger seeds were based on increase seed mass at different times of seed immersion in distilled water.

\subsection{Seedling Development}

The seedlings originated from seed germination experiment were used to evaluate the effects of seed size on time for seedling development and seedling vigor. The time for seedling development was defined as the time from seed germination (root protrusion) until seedling cotyledon fell. After cotyledon falling, seedlings were removed from substrate to determinate their length and dry mass of shoot and root system. The root and shoot lengths were determined with a digital caliper. In order to get dry biomass of root and shoot all seedlings were individually placed in paper bags, identified and transferred to an oven with air circulation at $60^{\circ} \mathrm{C}$ for 48 hours. After this time the dry weight of shoot and root system was determined on an analytical scale. Finally, the ratio of root: shoot biomass (RSR) of all seedlings was calculated as $\mathrm{RSR}=\left(\mathrm{W}_{\text {root }} / \mathrm{W}_{\text {shoot }}\right)$, where $\mathrm{W}_{\text {root }}$ is dry mass of the root and $\mathrm{W}_{\text {shoot }}$ is dry mass of shoots.

\subsection{Data Analysis}

Survival analysis was performed in order to test the effect of seed size on percentage and time for germination. Thus, germination percentage within each size class was used as response variables while the germination time was the explanatory variable. Survival analysis evaluates the likelihood of germination at a certain time avoiding the temporal pseudo-replication inherent to the data. The effect of seed size on seed water absorption was tested by constructing Generalized Linear Mixed Models (GLMM), since these data also showed temporal pseudo-replication. Thus, increased seed mass (Wr) at different times (2, 4, 8, 18, 24, 30 and 48 hours of water absorption) was used as the response variable and seed size classes as explanatory variable.

The effect of seed size on seedling development time, seedling vigor and resource allocation between root: shoot (RSR) was tested by constructing GLMs. Thus, to evaluate the effect of seed size on time of development of the seedlings, time required for the cotyledon to fall was the response variable and seed weight was the explanatory variable. To evaluate the effect of seed size on seedling vigor, length and dry weight of shoot and root system were the response variables and seed weight was the explanatory variable. To evaluate the differences in resource allocation, the root: shoot ratio (RSR) was used as the response variable and seed weight as explanatory variable. The hypotheses proposed in this study were tested on R software [30] and all of the models were constructed using an appropriate error distribution for each response variable [31].

\section{Results}

Seed germination percentage of Copaifera langsdorffii reached 72\%. Seed germination started in the eighth day 
after sawn and continued until the 55th day. The percentage of seed germination varied between seed size classes $\left(\chi^{2}=8.9, P<0.01\right)$ and small seeds have higher germination percentage (80\%) compared with large seeds (64.4\%). Time required for seed germination also varied between seed size classes $\left(\chi^{2}=11.02, P<0.001\right)$ with small seeds germinating faster than large seeds. The average time taken to $50 \%$ of small seeds germinate was approximately 29 days while the time for the same proportion of larger seeds germinate was about 42 days (Figure 1). The soaking test also showed that water absorption varied between seed size class $\left(F_{x, y}=22.56, P=0.003\right)$. In fact, small seeds were approximately two times more permeable to water than large seeds (Figure 2).

Seed weight positively affected time for cotyledon fall and ratio of root: shoot biomass of the seedlings (Table 1). Thus, seedlings originated from larger seeds retained their cotyledons for longer time compared with seedlings originated from smaller seeds (Figure 3(a)) and small seeds allocate proportionally more resources to root system compared to large seeds (Figure 3(b)). Furthermore, seed size positively affected dry weight of root and shoot, and shoot length of $C$. langsdorffii seedlings (Table 1, Figures 4(a)-(d)).

\section{Discussion}

Seed germination percentage of Copaifera langsdorffii was affected by seed size. However, the result was different than expected because the percentage of germination was $15.6 \%$ higher in small seeds. In addition, small seeds require less time for germination than large seeds, corroborating the general patterns (see [8]). At this point it is important to emphasize that increase in time for germination can cause seed viability loss due to deterioration and microorganisms attack [32]-[34]. Thus, this fact can be used to explain the variation in percentage of seed germination observed in this study.

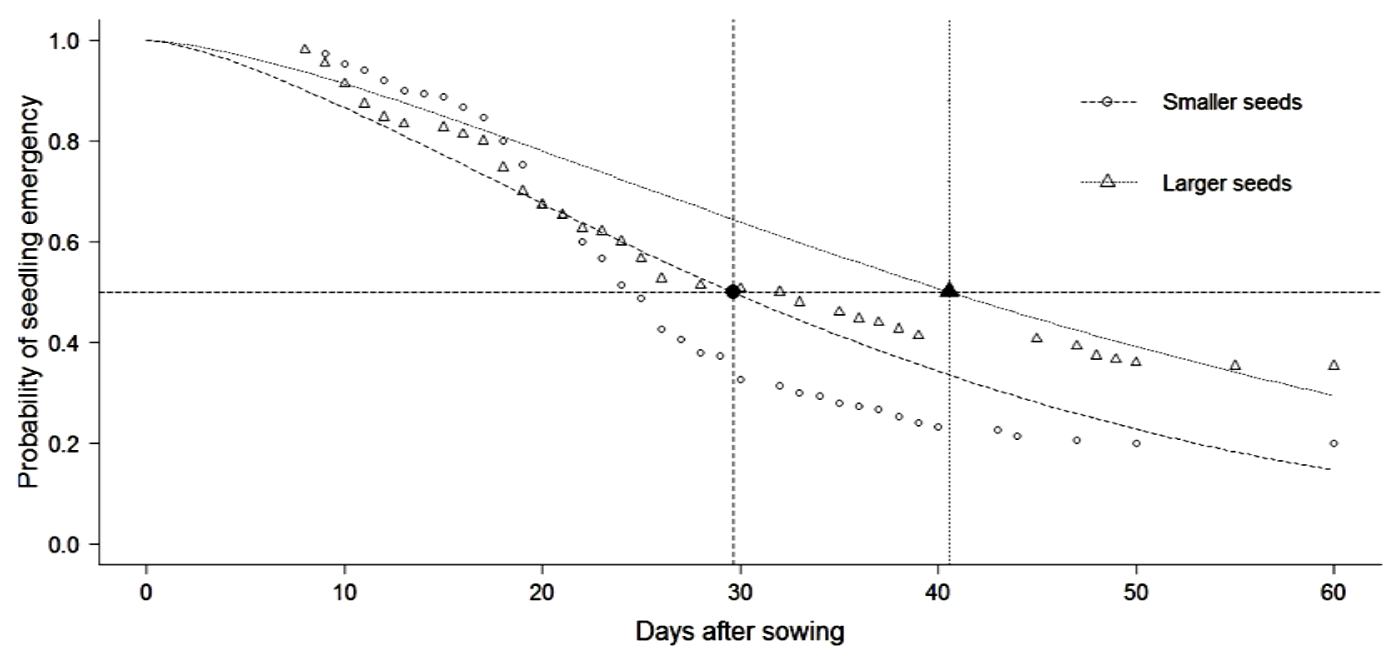

Figure 1. Germinability of Copaifera langsdorffii seeds between different size classes. Vertical lines indicate the time required for germination of $50 \%$ of smaller and larger seeds.

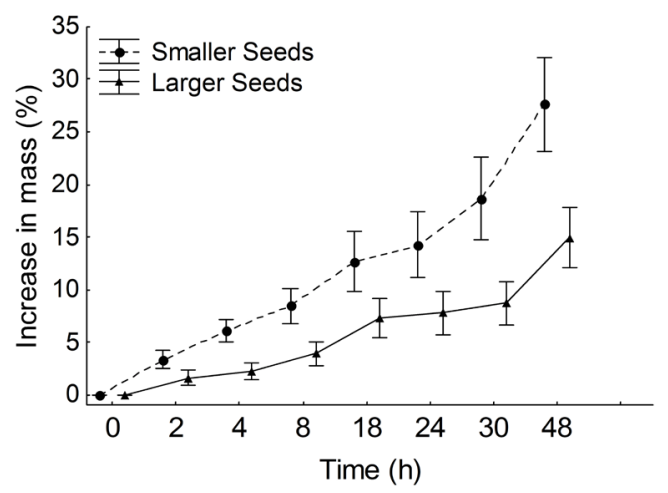

Figure 2. Imbibition curves for smaller and larger seeds of Copaifera langsdorffii. 


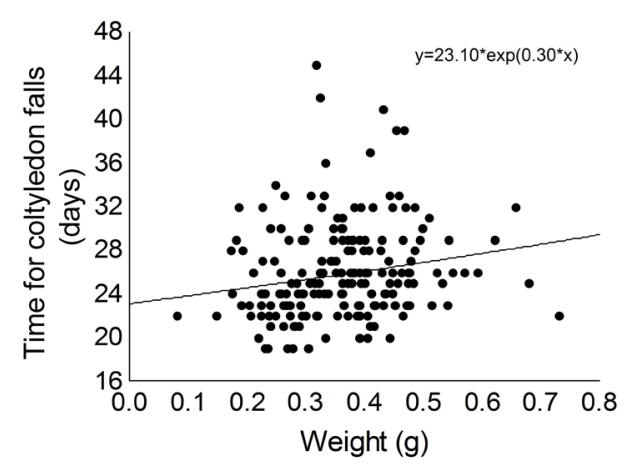

(a)

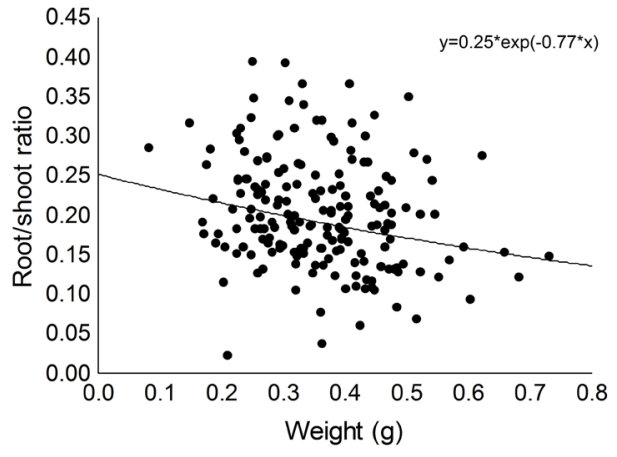

(b)

Figure 3. Relationship between seed weight and time for cotyledons fall (a) and ratio of root: shoot biomass (b) of Copaifera langsdorffii seedling.

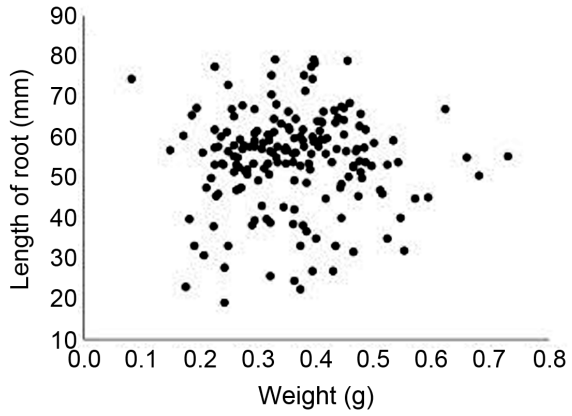

(a)

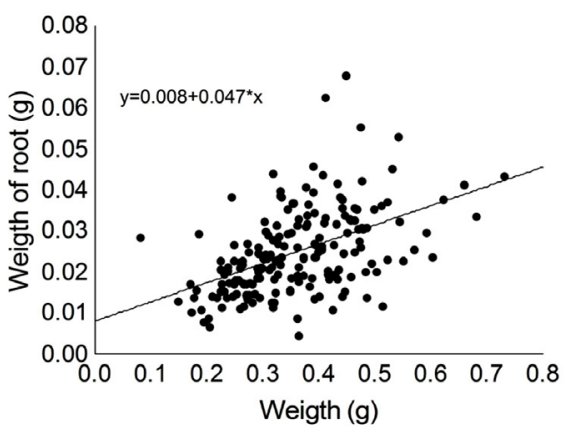

(c)

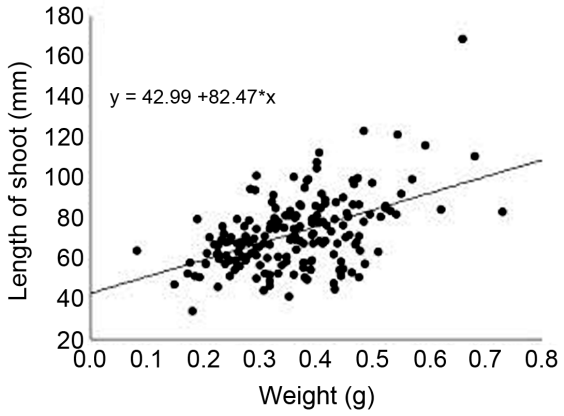

(b)

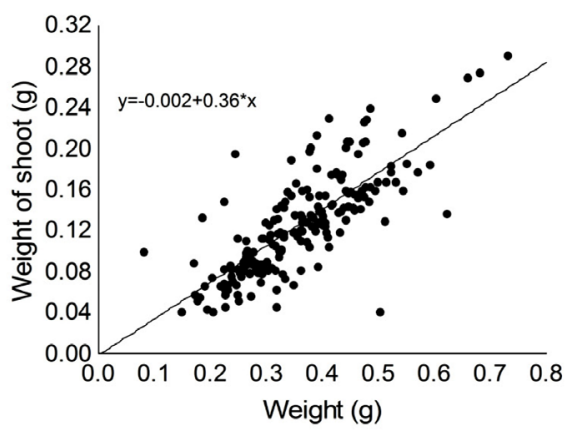

(d)

Figure 4. Relationship between seed weight and root length (a), shoot length (b), root dry weigh (c) and shoot dry weigh (d) of Copaifera langsdorffii seedling.

Small seeds of $C$. langsdorffii are more water permeable and germinate faster than large seeds. In general, seed size is directly related with seed coat thickness and inversely related with water absorption [35]. The increase in seed size also implies decrease in the surface: volume ratio, resulting in lower relative ability to absorb water and initiate the process of germination [36]. Thereby, smaller seeds have thinner coats and higher relative surface. This seed trait ensures greater permeability in small seeds and, consequently, less time for germination [37]. The fact that smaller seeds have thinner coat and high surface: volume ratio can justify effectively imbibition and variation in germination time between seed size classes of $C$. langsdorffii.

After germination, C. langsdorffii seedlings originated from larger seeds retained their cotyledons for longer time. Large seeds have higher amount of reserves in theirs cotyledons and need longer time to incorporate theses nutrients in seedling tissues [20]. Thus, seedlings originated from larger seeds have both more time for development and nutrients available for growth. Thus, the result observed in this study agrees with the general predic- 
Table 1. Deviance analysis of the complete models evaluating the effect of seed weight on initial development and resource allocation of Copaifera langsdorffii seedlings.

\begin{tabular}{ccccccc}
\hline Explanatory variable & Response variable & Deviance & Residual Df. & Residual deviance & $X^{2}$ & $P$ \\
\hline & Time for cotyledons fall & 5.0181 & 180 & 116.32 & 5.0181 & $<0.01$ \\
& Length of shoot (mm) & 13659 & 180 & 43381 & 56.676 & $<0.001$ \\
& Length of root (mm) & 5.6645 & 180 & 26246 & 0.0386 & 0.8444 \\
\multirow{2}{*}{ Seed weight } & Weight of shoot (g) & 0.0048 & 180 & 0.015 & 58.52 & $<0.001$ \\
& Weight of root (g) & 0.2773 & 180 & 0.153 & 325.79 & $<0.001$ \\
& root: shoot ratio & 0.0184 & 180 & 0.768 & 0.0184 & $<0.05$ \\
\hline
\end{tabular}

tion that larger seeds produce seedlings with larger initial size as reported by others authors [4] [10] [23] [38] [39]. In this scenario it would be reasonable to think that larger seeds/seedlings have higher competitive ability relative to small seeds. However, several other forces act synergistically to shape seed size. For example, nutritionally stressed habitat acts in favor of larger seeds/seedlings because larger seedlings (originated from larger seeds) have more nutritional reserves [2] [19] [40] [41]. On the other hand, larger seeds are preferentially attacked by predators, favoring smaller seeds survivorship [42].

Another important aspect of the relation between seed and seedling size is related with resource allocation for root or shoot. In general, seedlings originated from smaller seeds must allocate a greater proportional amount of resources to roots development, resulting in higher root: shoot ratio [22] as observed in this study. The high investment in root tissues promotes greater development of root systems that reach deeper levels of substrate with more water and nutrients [43]. Thus, this resource reallocation between root and shoot could increase the survivorship chance of seedlings with poor cotyledons reserves.

Within a given population, plants should develop seeds of similar size because there is often a single best range of seed size that optimizes the local fitness [44]. However, seed size within species is one of the more plastic components of plant life history [45]. It is plausible that the variation in seed size within species is associated with differential seed performance among habitats [46]. For example, smaller seeds are favored in transient habitats, because they present greater percentage of germination and germinate more quickly. In contrast, larger seeds have more reserves, producing vigorous seedlings that present greater competitive ability in predictable habitats. The $C$. langsdorffii seeds showed broad variation in biomass. This variation in seed size allows the species to colonize different habitats, helping to justify C. langsdorffii widespread geographic distribution.

\section{Acknowledgements}

We thank all the collaborators of the Laboratório de Biologia da Conservação da UNIMONTES for logistical support in the fieldwork. This study was carried out with financial support from Fundação de Amparo a Pesquisa do Estado de Minas Gerais (FAPEMIG APQ 01926.11) and Programa de Pós-Graduação Stricto Sensu em Ciências Biológicas (PPGCB) da UNIMONTES. The authors also acknowledge CAPES and FAPEMIG by research grants.

\section{References}

[1] Wulff, R.D. (1986) Physiological Performance Seed Size Variation in Desmodium paniculatum. Journal of Ecology, 74, 99-114. http://dx.doi.org/10.2307/2260351

[2] Armstrong, D.P. and Westoby, M. (1993) Seedlings from Large Seeds Tolerated Defoliation Better: A Test Using Phylogeneticaly Independent Contrasts. Ecology, 74, 1092-1100. http://dx.doi.org/10.2307/1940479

[3] Burmeier, S. and Jensen, K. (2008) Is the Endangered Apium repens (Jacq.) Lag. Rare Because of a Narrow Regeneration Niche? Plant Species Biology, 23, 111-118. http://dx.doi.org/10.1111/j.1442-1984.2008.00212.x

[4] Fagundes, M., Camargos, M.G. and Costa, F.V. (2011) A Qualidade do solo afeta a Germinação das Sementes e o Desenvolvimento das Plântulas de Dimorphandra mollis Benth. (Leguminosae: Mimosoidae). Acta Botanica Brasílica, 25 , 908-915.

[5] Ranieri, B.D., Pezzini, F.F., Garcia, Q.S., Chautems, A. and França, M.G.C. (2012) Testing the Regeneration Niche 
Hypothesis with Gesneriaceae (tribe Sinningiae) in Brazil: Implications for the Conservation of Rare Species. Austral Ecology, 37, 125-133. http://dx.doi.org/10.1111/j.1442-9993.2011.02254.X

[6] Marques, M.C.M. and Oliveira, P.E.A.M. (2005) Características Reprodutivas das Espécies Vegetais da Planície Litorânea. História Natural e Conservação da Ilha do Mel. Editora da Universidade Federal do Paraná, Paraná.

[7] Cordazzo, C.V. (2002) Effect of Seed Mass on Germination and Growth in Three Dominant Species in Southern Brazilian Coastal Dunes. Brazilian Journal of Biology, 62, 427-435. http://dx.doi.org/10.1590/S1519-69842002000300005

[8] Murali, K.S. (1997) Patterns of Seed Size, Germination and Seed Viability of tropical Tree Species in Southern India. Biotropica, 29, 271-279. http://dx.doi.org/10.1111/j.1744-7429.1997.tb00428.x

[9] Mölken, T., Jorritsma-Wienk, L.D., Hoek, P.H. and Kroon, W.H. (2005) Only Seed Size Matters for Germination in Different Populations of the Dimorphic Tragopogonp ratensiss subsp. pratensis (Asteraceae). American Journal of Botany, 92, 432-437. http://dx.doi.org/10.3732/ajb.92.3.432

[10] Yanlong, H., Mantang, W., Shujun, W., Yanhui, Z., Tao, M. and Guozhen, D. (2007) Seed Size Effect on Seedling Growth under Different Light Conditions in the Clonal Herb Ligularia virgaurea in Qinghai-Tibet Plateau. Acta Ecologica Sinica, 27, 3091-3108. http://dx.doi.org/10.1016/S1872-2032(07)60063-8

[11] Silveira, F.A.O., Negreiros, D., Araújo, L.M. and Fernandes, G.W. (2012) Does Seed Germination Contribute to Ecological Breadth and Geographic Range? A Test with Sympatric Diplusodon (Lythraceae) Species from Rupestrian Fields. Plant Species Biology, 27, 170-173. http://dx.doi.org/10.1111/j.1442-1984.2011.00342.x

[12] Leishman, M.R., Westoby, M. and Jurado, E. (1995) Correlates of Seed Size Variation: A Comparison among Five Temperate Floras. Journal of Ecology, 83, 517-529. http://dx.doi.org/10.2307/2261604

[13] Silvertown, J. and Bullock, J.M. (2003) Do Seedlings in Gaps Interact? A Field Test of Assumptions in ESS Seed Size Models. Oikos, 101, 499-504. http://dx.doi.org/10.1034/j.1600-0706.2003.12247.x

[14] Moles, A.T. and Westoby, M. (2006) Seed Size and Plant Strategy across the Whole Life Cycle. Oikos, 113, 91-105. http://dx.doi.org/10.1111/j.0030-1299.2006.14194.x

[15] Baskin, C.C. and Baskin, J.M. (1998) Seeds—Ecology, Biogeography, and Evolution of Dormancy and Germination. Academic Press, New York.

[16] Harper, J.L. (1977) Population Biology of Plants. Academic Press, New York.

[17] Geritz, S.A. (1995) Evolutionarily Stable Seed Polymorphism and Small-Scale Spatial Variation in Seedling Density. The American Naturalist, 146, 685-707. http://dx.doi.org/10.1086/285820

[18] Ferreira, A.G. and Borghetti, F. (2004) Germinação: Do Básico ao Aplicado. Editora Artmed, Porto Alegre.

[19] Mendes-Rodrigues, C., Oliveira, P.E. and Ranal, M.A. (2011) Seed Germination and Seedling Growth of two Pseudobombax species (Malvaceae) with Contrasting Habitats from Brazilian Cerrado. Revista de Biologia Tropical, 59, 1915-1925.

[20] Primack, R.B. (1987) Relatioship among Flower, Fruits, and Seeds. Annual Review of Ecology and Systematics, 18, 409-430. http://dx.doi.org/10.1146/annurev.es.18.110187.002205

[21] Agren, G.I. and Franklin, O. (2003) Root: Shoot Ratios, Optimization and Nitrogen Productivity. Annals of Botany, 92, 795-800. http://dx.doi.org/10.1093/aob/mcg203

[22] Yang, Z. and Midmore, D.J. (2005) Modeling Plant Resource Allocation and Growth Partitioning in Responses to Environmental Heterogeneity. Ecological Modelling, 181, 59-77. http://dx.doi.org/10.1016/j.ecolmodel.2004.06.023

[23] Leishman, M.R. (2001) Does the Seed Size/Number Trade-Off Model Determine Plant Community Structure: An Assessment of the Model Mechanisms and Their Generality. Oikos, 93, 294-302. http://dx.doi.org/10.1034/j.1600-0706.2001.930212.x

[24] Rego, R.S., Silva, A.J.C., Brondani, G.E., Grisi, F.A., Nogueira, A.C. and Kuniyoshi, Y.S. (2007) Caracterização Morfológica do Fruto, Semente e Germinação de Duranta vestita Cham. (Verbenaceae). Revista Brasileira de Biociências, 5, 474-476.

[25] Carvalho, P.E.R. (2003) Espécies Arbóreas Brasileiras. Embrapa Florestas, Colombo, Brasília.

[26] Pedroni, F., Sanchez, M, and Santos, A.M. (2002) Fenólogia da Copaíba (Copaifera langsdorffii Desf.—Leguminosae, Caesalpinioideae) em Uma Floresta Semidecídua no Sudeste do Brasil. Revista Brasileira de Botânica, 25, 183-194.

[27] Fagundes, M., Maia M.L.B., Queiroz, A.C.M., Fernandes, G.W. and Costa F.V.(2013) Seed predation of Copaifera langsdorffii Desf. (Fabaceae: Caesalpinioideae) by Rhinochenus brevicollis Chevrolat (Coleoptera: Curculionidae) in a Cerrado Fragment. Ecología Austral, 23, 218-221.

[28] Costa, F.V., Siqueira, F.N., Oliveira, J.S. and Fagundes, M. (2011) Relationship between Plant Development, Tannin Concentration and Insects Associated with Copaifera langsdorffii (Fabaceae). Arthropod-Plant Interactions, 5, 9-18. http://dx.doi.org/10.1007/s11829-010-9111-6 
[29] Baskin, J.M. and Baskin, C.C. (2004) A Classification System for Seed Dormancy. Seed Science Research, 14, 1-16. http://dx.doi.org/10.1079/SSR2003150

[30] R Development Core Team (2008) R: A Language and Environment for Statistical Computing. R Foundation for Statistical Computing, Vienna. http://www.rproject.org

[31] Crawley, M.J. (2007) The R Book. John Wiley and Sons, New York. http://dx.doi.org/10.1002/9780470515075

[32] Walters, C. (1998) Understanding the Mechanisms and Kinetics of Seed Aging. Seed Science Research, 8, $223-244$. http://dx.doi.org/10.1017/S096025850000413X

[33] Debeaujon, I., Léon-Kloosterziel, K.M. and Koornneef, M. (2000) Influence of the Testa on Seed Dormancy, Germination, and Longevity in Arabidopsis. Plant Physiology, 122, 403-414. http://dx.doi.org/10.1104/pp.122.2.403

[34] Gharoobi, B. (2011) Effects of Seed Size on Seedlings Characteristics of Five Barley Cultivars. Iranian Journal of Plant Physiology, 1, 265-270.

[35] Beninger, C.W., Hosfield, G.L. and Nair, M.G. (1998) Physical Characteristics of Dry Beans in Relation to Seed Coat Color Genotype. HortScience, 33, 328-329.

[36] Fowler, A.J.P. and Bianchetti, A. (2000) Dormência em sementes florestais. Embrapa Florestas, Colombo, Paraná.

[37] Dolan, R.W. (1984) The Effect of Seed Size and Maternal Source on Individual Size in a Population of Ludwigia leptocarpa (Onagraceae). American Journal of Botany, 71, 1302-1307. http://dx.doi.org/10.2307/2443655

[38] Dan, E.L., Mello, V.D.C., Wetzel, C.T., Popinigis, F. and Zonta, E.P. (1987) Transferência de Matéria seca Como Método de Avaliação do Vigor de Sementes de Soja. Revista Brasileira de Sementes, 9, 45-55.

[39] Westoby, M., Leishman, M., Lord, J., Porter, H. and Schoen, D.J. (1996) Comparative Ecology of Seed Size and Dispersal. Philosophical Transactions of the Royal Society B, 351, 1309-1318. http://dx.doi.org/10.1098/rstb.1996.0114

[40] Gross, K.L. (1984) Effects of Seed Size and Growth Form on Seedling Establishment of Six Monocarpic Perennial Plants. Journal of Ecology, 72, 369-387. http://dx.doi.org/10.2307/2260053

[41] Foster, S.A. (1986) On the Adaptive Value of Large Seeds for Tropical Moist Forest Trees: A Review and Synthesis. Botanical Review, 52, 260-299. http://dx.doi.org/10.1007/BF02860997

[42] Souza, M.L. and Fagundes, M. (2014) Predispersal Seed Predation of Copaifera langsdorffii (Fabaceae): A Tropical Tree with Supra-Annual Mass Fruiting in Brazilian Cerrado. Arthropod-Plant Interactions.

[43] Canadell, J. and Zedler, P.H. (1995) Underground Structures of Woody Plants in Mediterranean Ecosystems of Australia, California and Chile. Ecology and Biogeography of Mediterranean Ecosystems in Chile, California and Australia. Springer-Verlag, New York.

[44] Rees, M. and Westoby, M. (1997) Game-Theoretical Evolution of Seed Mass in Multi-Species Ecological Models. Oikos, 78, 116-126. http://dx.doi.org/10.2307/3545807

[45] Harper, J.L., Lovell, P.H. and Moore, K.G. (1970) The Shapes and Size of Seeds. Annual Review of Ecology and Systematics, 1, 327-356. http://dx.doi.org/10.1146/annurev.es.01.110170.001551

[46] Bu, H.Y., Du, G.Z., Chen, X.L., Wang, Y., Xu, X.L. and Liu, K. (2009) The Evolutionary Significance of Seed Germinability in an Alpine Meadow on the Eastern Qinghai-Tibet Plateau. Arctic, Antarctic, and Alpine Research, 41, 97102. http://dx.doi.org/10.1657/1523-0430-41.1.97 
Scientific Research Publishing (SCIRP) is one of the largest Open Access journal publishers. It is currently publishing more than 200 open access, online, peer-reviewed journals covering a wide range of academic disciplines. SCIRP serves the worldwide academic communities and contributes to the progress and application of science with its publication.

Other selected journals from SCIRP are listed as below. Submit your manuscript to us via either submit@scirp.org or Online Submission Portal.
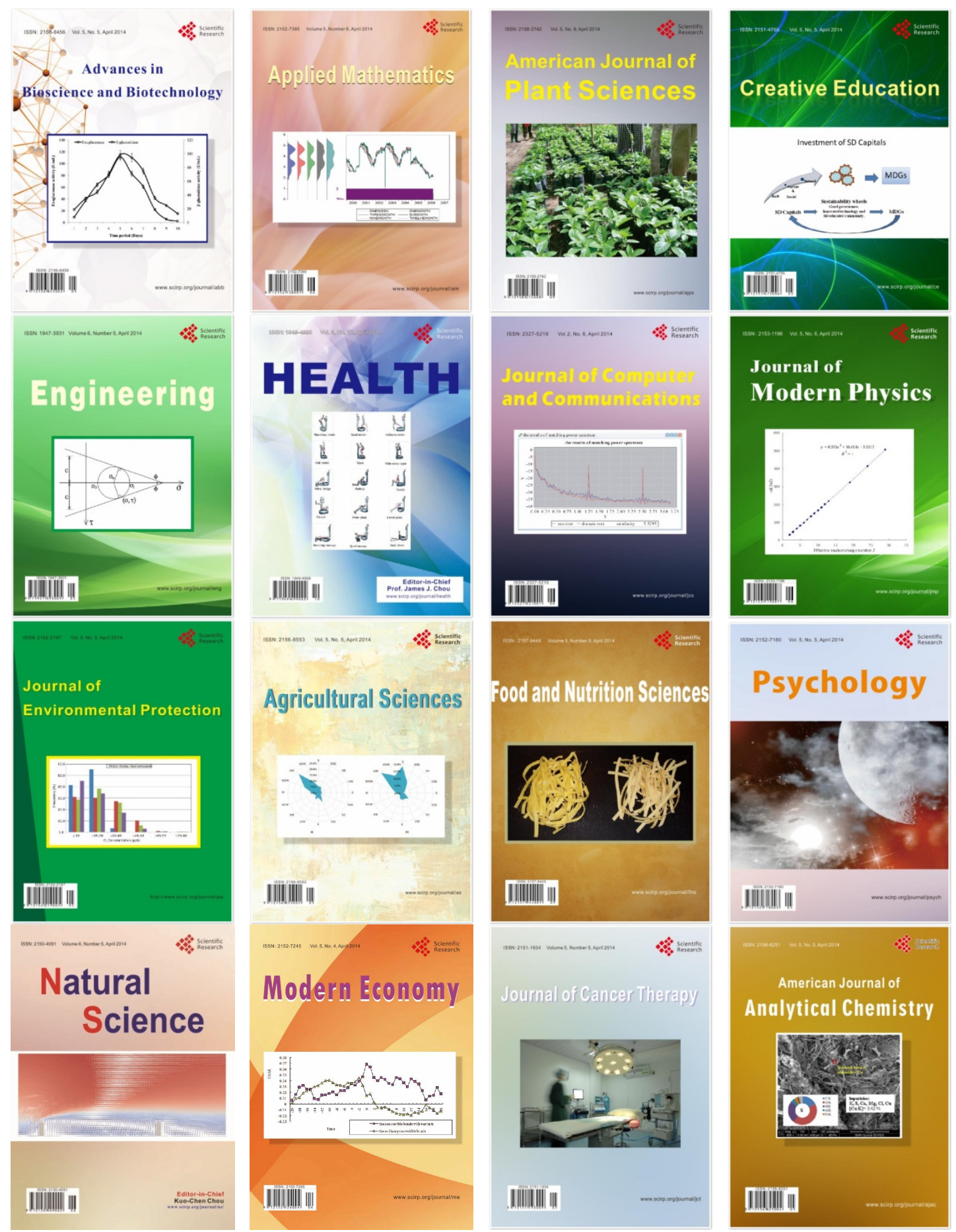